\title{
Character association and path coefficient analysis for identification of yield enhancing characters in snake gourd (Trichosanthes anguina L.)
}

\author{
S. Islam, R. Hasan, A. Bashar, M. K. Hossain, A. K. M. M. Huque ${ }^{1}$ and N. Alam* \\ Plant Breeding and Crop Improvement Laboratory, Department of Botany \\ Jahangirnagar University, Savar, Dhaka-1342, Bangladesh
}

\begin{abstract}
Correlations and path coefficient were studied in seven snake gourd genotypes namely Turag, Surma, Vorosa, Manghosito, Jhumlong, Green nitch and Monosha for yield and eleven yield contributing characters. The correlation coefficients were determined to find out the interrelationship among the characters studied. The correlation studies revealed that, yield/plant had positive and highly significant correlation both in phenotypic and genotypic level with fresh weight/fruit, fruit girth, fruits/plant, plant height and fruit length which indicated that yield could be increased by selecting these characters. Direct and indirect effects were measured using path coefficient analysis in order to obtain mechanisms of interrelationship between yield/plant and its components. The highest positive direct effect $(0.9763)$ on yield/plant was found in fresh weight/fruit followed by fruits/plant (0.4179) and fruit length $(0.2665)$. The characters showed direct positive effect on yield/plant indicated that direct selection for these traits might be effective for improving yield through selection in snake gourd.
\end{abstract}

Key words: Coefficient analysis, yield characters, snake gourd.

\section{INTRODUCTION}

Snake gourd (Trichosanthes anguina L.) is a common summer vegetable consumed and relished by most of the people of Bangladesh. It is an annual monoecious climbing herbaceous crop belonging to the family cucurbitaceae having chromosome number $2 \mathrm{n}=22$ (Jeffery, 1980 and Chakarbati, 1982). It is commonly known as "Chichinga" in Bangladesh and also known as "Chinese cucumber"around the world. It is widely grown in India, Sri Lanka, Thailand, China, Australia and Africa. Snake gourd is important as a good source of minerals, fibers and other nutrients, these make the food wholesome and healthy (Varghese \& Rajan, 1993). Snake gourd acts as an excellent anti-inflammatory. Inflammation if left ignored can result in serious illness like, diabetes, heart attacks, stroke, cancer, mood disorders, sleep disorders, arthritis and alzheimer. It is gaining popularity for being an integral part of the anti-inflammatory diet chart. The use of snake gourd in alternative medicine is increasing because of its curative properties.

Among the few vegetables it fetches more yields per unit area but the average yield of the crop is low in Bangladesh than that of the others neighboring countries. The yield of snake gourd is very low and its production is also restricted to only to 3-4 months of the

\footnotetext{
${ }^{1}$ Plant Molecular Genetics Lab., Division of Life Sciences, Korea University, Seoul 136-701, South Korea

* Corresponding author E-mail: nazmul_alam@gmail.com
} 
year in Bangladesh (BBS 2012). There is no high yielding variety of snake gourds in Bangladesh but there is a wide range of variability in size, shape and color of fruits in Bangladesh (Rashid, 1993). A large number of land races of snake gourd are cultivated in the country but no cultivar of this crop is yet recommended for this country. No adequate attempt has so far been made to increase the productivity of this crop. The productivity of the vegetable can be increased to a greater extent through varietal improvement.

For developing superior snake gourd varieties, it is necessary to improve its yield components. Yield is a resultant character which is relatively and simply inherited (Rao et al., 1990). Many characters of snake gourd are interrelated either in desirable or in undesirable direction. Correlation coefficients measure the mutual relationship between various pairs of characters and help in identifying the component characters on which selection can be based for improvement in yield. Again the implication of correlation studies become more evident when correlations are partitioned into cause (component) and effect (yield) through path analysis in order to determine the relative magnitudes of various attributes contribute to build up the associations. Plant breeders can exploit the information regarding character association and path analysis for the development of commercial variety or hybrid in snake gourd. Hence, an attempt has been made in the present investigation to study the association of different traits, direct and indirect effects of characters based on per se performance.

\section{MATERIALS AND METHODS}

The present investigation was conducted during (February-June) 2013 at the Botanical Garden of Jahangirnagar University, Savar, Dhaka. The experimental materials consisted of seven genotypes of snake gourd namely Turag, Surma, Vorosa, Manghosito, Jhumlong, Green nitch and Monosha collected from different sources like local seed market, certified seed company and national research institution of Bangladesh. The experiment was laid out in Randomized Complete Block Design (RCBD) with three replications. The unit pits was $120 \times 120 \mathrm{~cm}$ maintaining a plant spacing of $30 \times 30 \mathrm{~cm}$. A distance of $60 \mathrm{~cm}$ in the form of drain was maintained between the block and between the plots within a block. The genotypes were randomly assigned in different blocks. The soil of the experimental field was sandy loam in texture and belongs to the 'Shallow Red Brown Terrace' under Madhupur tract with a pH of around 6.2-6.8 (Haider et al.,1991 and Anon.1998).The fertilizer and manure were applied as per recommended dose and the cultural practice were followed when required.

Data were recorded randomly for twelve quantitative traits such as plant height $(\mathrm{cm})$, primary branches/plant, terminal leaflet length $(\mathrm{cm})$, terminal leaflet breadth $(\mathrm{cm})$, days to first flowering, fruits/plant, fruit length $(\mathrm{cm})$, fruit girth $(\mathrm{cm})$, fresh weight/fruit $(\mathrm{g})$, inter node length $(\mathrm{cm})$, number of nodes /plant and yield /plant $(\mathrm{g})$. For all each characters, except days to first flowering ten randomly selected plants of each genotype from each replication were considered to record data. 
The collected data were compiled and tabulated in proper forms for statistical analysis. Genotypic and phenotypic correlation coefficients were calculated according to the formula suggested by Johnson et al. (1955) and Hanson et al. (1956). Correlation coefficient were further partitioned into components of direct and indirect effects by path coefficient analysis originally developed by Wright (1921) and later described by Dewey \& Lu (1959).

\section{RESULTS AND DISCUSSION}

Significant genetic variation has been found among seven snake gourd genotypes for yield and yield attributing traits (Table 1). Highest variation was found for fruit length and fresh weight/fruit. Yield/plant, terminal leaf length and fruits/plant showed moderate variation and other characters showed low genetic variation. Maximum yield was found for green nitch genotype and other genotypes such as surma, turag also showed higher yield.

Correlation coefficients analysis: Estimates of genotypic and phenotypic correlation coefficient between yield and its eleven component characters in all possible combinations are presented in Table1. In general, genotypic correlation coefficients were higher than phenotypic correlation coefficients, which indicated the association was largely due to genetic reason and masked efficiently environment effects which may modify the expression of the characters thereby reduced the phenotypic expression at a bit of lesser extent. (Saha et al., 1992, Islam, 1993, Huque et al., 2012).

Fruit yield had significant positive genotypic and phenotypic correlation with fresh weight $/$ fruit $\left(r_{g}=0.837^{* *}, r_{p}=0.836^{* *}\right)$, fruit girth $\left(r_{g}=0.674 *, r_{p}=0.672^{*}\right)$ but only positive with fruit/plant $\left(r_{g}=0.367, r_{p}=0.367\right)$ (Table 2). Similar results has been reported by Narayanankutty et al. (2006) where they found fruit yield was strongly correlated with fruit weight, fruits/plant, fruit girth, fruit length, days to first harvest, flesh thickness and days to first female flower opening. Rana et al. (2011) reported significant positive correlation of number of fruits/plant, total number of primary branches and number of nodes/plant with fruit yield. Rahman et al. (2002) found significant positive genotypic and phenotypic correlation of number of fruits/plant and fruit length with fruit yield. Islam et al. (1993) found significant positive genotypic and phenotypic correlation of number of fruits/plant and average fruit weight with fruit yield in cucumber. Number of nodes/plant showed significant positive genotypic and phenotypic correlations with plant height $\left(r_{\mathrm{g}}=0.972^{* *}, \mathrm{r}_{\mathrm{p}}=0.962^{* *}\right)$, primary branches/plant $\left(\mathrm{r}_{\mathrm{g}}=0.970^{* *}, \mathrm{r}_{\mathrm{p}}=0.922^{* *}\right)$, Days to first flowering $\left(r_{\mathrm{g}}=0.847 * *, \mathrm{r}_{\mathrm{p}}=0.795^{* *}\right)$, terminal leaflet breadth $\left(\mathrm{r}_{\mathrm{g}}=0.748^{* *}, \mathrm{r}_{\mathrm{p}}\right.$ $\left.=0.715^{* *}\right)$ and terminal leaflet length $\left(\mathrm{r}_{\mathrm{g}}=0.713^{* *}, \mathrm{r}_{\mathrm{p}}=0.682^{*}\right)$, respectively $($ Table 2$)$.

Fresh weight/fruit showed positive significant correlation both at genotypic and phenotypic level with fruit girth $\left(\mathrm{r}_{\mathrm{g}}=0.893^{* *}, \mathrm{r}_{\mathrm{p}}=0.889^{* *}\right)$. Days to first flowering also showed positive significant correlation both at genotypic and phenotypic level with plant height $\left(\mathrm{r}_{\mathrm{g}}=0.822^{* *}, \mathrm{r}_{\mathrm{p}}=0.782^{* *}\right)$ and Primary branches/plant $\left(\mathrm{r}_{\mathrm{g}}=0.824^{* *}, \mathrm{r}_{\mathrm{p}}=0.682 *\right)$ (Table 2). 
Islam et al.

Table 1. Mean performances of yield and yield contributing characters in snake gourd genotypes

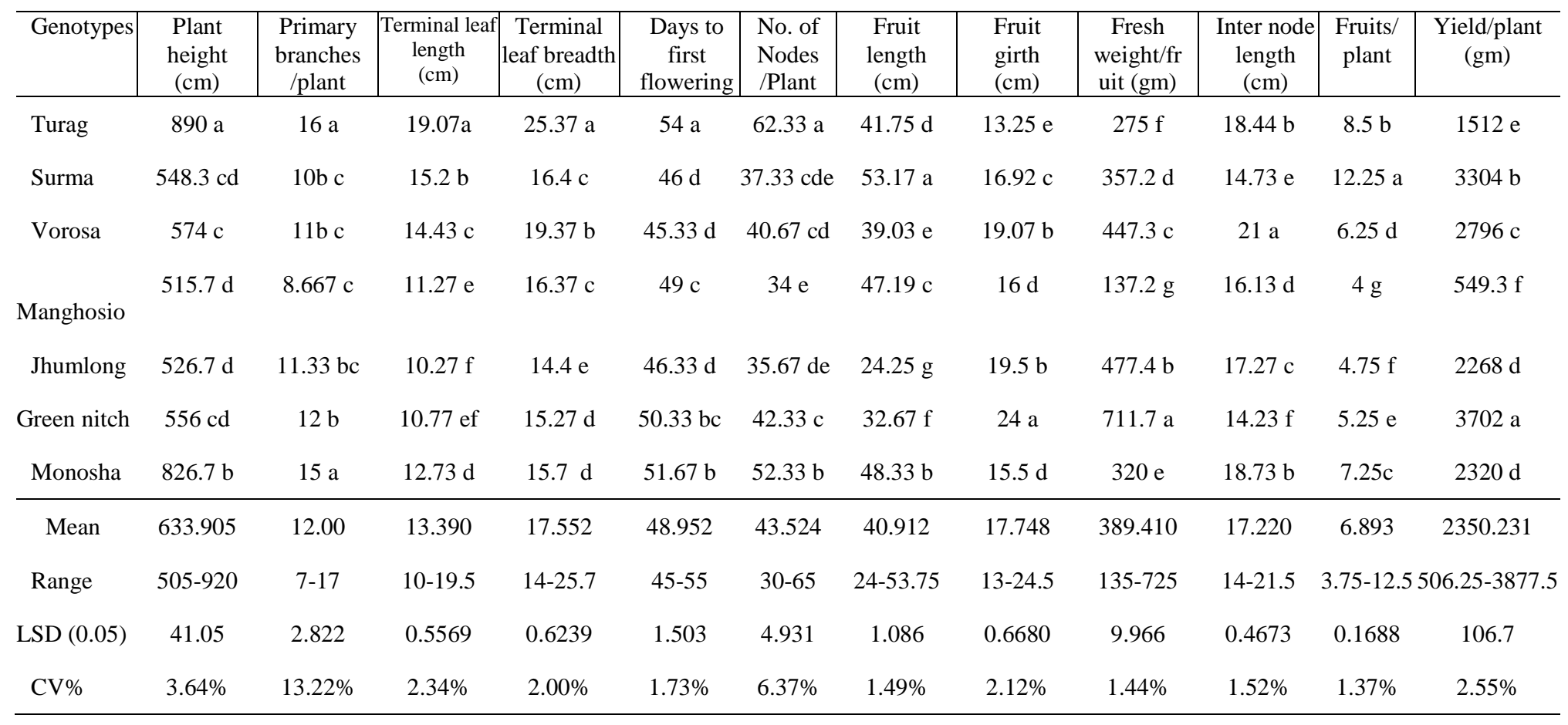


Character association, path analysis, yield characters, snake gourd

61

Table 2. Genotypic $\left(r_{g}\right)$ and Phenotypic $\left(r_{p}\right)$ coefficient between yield and yield contributing characters in snake gourd genotypes

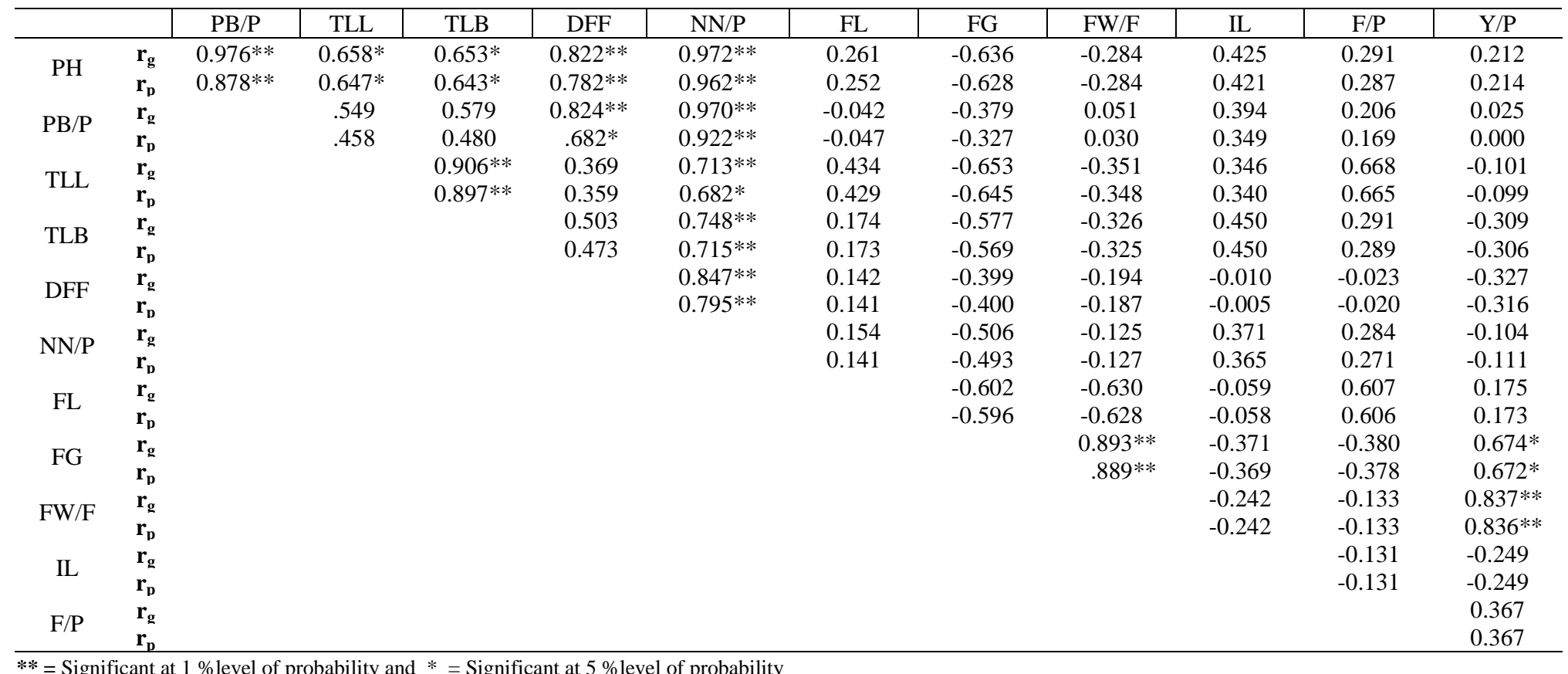

$* *=$ Significant at $1 \%$ level of probability and $*=$ Significant at $5 \%$ level of probability
Note: $\mathrm{PH}=$ Plant height, $\mathrm{PB} / \mathrm{P}=$ Primary branches $/$ plant, TLL= Terminal leaf length, TLB= Terminal leaf breadth, DFF= Days to first flowering,

Note: $\mathrm{PH}=\mathrm{Plant}$ height, $\mathrm{PB} / \mathrm{P}=\mathrm{Primary}$ branches $/ \mathrm{plant}$, $\mathrm{TLL}=$ Terminal leaf length, $\mathrm{TLB}=\mathrm{Terminal}$ leaf breadth, DFF= Days to first flowering,
$\mathrm{NN} / \mathrm{P}=$ Number of nodes $/ \mathrm{plant}, \mathrm{FL}=$ Fruit length, FG= Fruit girth, FW/F= Fresh weight $/$ fruit, IL= Inter node length,F/P= Fruits /plant and $\mathrm{Y} / \mathrm{P}=\mathrm{Yield} / \mathrm{plant}$. 
Positive significant correlation both at genotypic and phenotypic level was found between plant height and primary branches/plant $\left(r_{g}=0.976^{* *}, r_{p}=0.878^{* *}\right)$. Negative correlation of yield/plant both genotypically and phenotypically were measured with terminal leaflet length, terminal leaflet breadth, days to first flowering, inter node length and number of nodes/plant.

In general, the association of the characters could be explained in a way that total fluctuation in yield are governed mainly by changing in one or more components ; though all fluctuation in the components as in each of cases were not expressed in yield due to decisive ratings of desirable and undesirable associations of the components with yield/plant (Graffius, 1964). Moreover, the knowledge of nature and magnitude of association between yield and its components is necessary for effective selection in advance generation. Correlations between pairs of characters were developed due to either linkage of genes or pleiotropic gene action (Narolia et al., 2012). Therefore, emphasis for selection of the components in positive direction for higher yield/plant may be suggested for effective yield improvement in snake gourd.

Path coefficient analysis: Association of characters as determined by simple correlation coefficient did not provide an exact picture of the relationship between yield components and yield. Path coefficient analysis, in contrast, permitted a critical examination of specific direct and indirect effects of characters and measured the relative importance of each of characters in determining the mechanism of correlation of yield /plant with other characters (Table 3 and Fig.1). In the present investigation, in general, the genotypic correlation coefficient of a pair of characters was higher than corresponding phenotypic correlation coefficient which might be due to re deduction error (environmental variance), hence only the genotypic correlation coefficients of yield/plant with other characters were divided into a series of direct and indirect effects through path coefficient analysis.

Path coefficient analysis showed that fresh weight/fruit had maximum direct effect (0.9763) followed by fruits/plant (0.4179) and fruit length (0.2665). Similar observations were found by Narayanankutty et al. (2006) where they reported that fruit weight and fruits/plant hade the maximum positive direct effects on yield. However, Rahman et al. (2002) reported that number of fruits/plant had the maximum direct effect (0.989) followed by average fruit weight (0.231). Miahet et al. (2000) found that average fruit weight had maximum direct contribution (1.699) on yield of bitter gourd followed by number of fruits per plant (0.932). Saha et al. (1992) also observed positive direct effect for number of fruits/plant, fruit length on fruit yield in pumpkin. Rana et al. (2011) reported days to first female flower opening had the highest direct positive effect on yield. Fresh weight/fruit showed highest direct effect towards yield/plant via maximum positive indirect effect of fruit girth (0.0865). On the contrary, Narayanankutty et al. (2006) reported higher indirect contribution of days to first harvest, seeds/fruit and hundred seed weight over fresh weight/fruit. The residual effect was 0.015 indicated that about 98.5 percent of the variability in yield was contributed by eleven characters studied in path analysis. Number of nodes/plant had high negative direct effect $(-0.1525)$ on yield per plant followed by terminal leaf breadth (-0.1448) and days to first flowering (0.0465).Fresh weight/fruit had positive indirect effects (0.8719) via fruit girth followed by fruits/plant $(0.2792)$ via terminal leaf length. Negative indirect effect was found in fresh weight/fruit $(-0.6152)$ via fruit length and followed by plant height $(-0.2775)$. 
Character association, path analysis, yield characters, snake gourd

Table 3. Direct (bold) and indirect effects of different yield attributes on yield of snake gourd

\begin{tabular}{|c|c|c|c|c|c|c|c|c|c|c|c|c|}
\hline & $\mathrm{PH}$ & $\mathrm{PB} / \mathrm{P}$ & TLL & TLB & DFF & $\mathrm{NN} / \mathrm{P}$ & FL & FG & $\mathrm{FW} / \mathrm{F}$ & IL & $\mathrm{F} / \mathrm{P}$ & $\begin{array}{c}\text { Total } \\
\text { genotypic } \\
\text { correlation } \\
\text { to yield }\end{array}$ \\
\hline $\mathrm{PB} / \mathrm{P}$ & 0.1152 & 0.0188 & 0.0155 & -0.0839 & -0.0383 & -0.1479 & -0.0111 & -0.0367 & 0.0493 & 0.0579 & 0.086 & 0.0248 \\
\hline TLL & 0.0777 & 0.0103 & 0.0282 & -0.1312 & -0.0172 & -0.1088 & 0.1157 & -0.0632 & -0.343 & 0.0508 & 0.2792 & -0.1013 \\
\hline NN/P & 0.1149 & 0.0182 & 0.0201 & -0.1083 & -0.0394 & -0.1525 & 0.041 & -0.049 & -0.1222 & 0.0546 & 0.1187 & -0.1039 \\
\hline FL & 0.0308 & -0.0008 & 0.0123 & -0.0252 & -0.0066 & -0.0235 & 0.2665 & -0.0583 & -0.6152 & -0.0086 & 0.2538 & -0.1748 \\
\hline FG & -0.0752 & -0.0071 & -0.0184 & 0.0835 & 0.0186 & 0.0771 & -0.1603 & 0.0969 & 0.8719 & -0.0545 & -0.1586 & $0.6737 *$ \\
\hline FW/F & -0.0336 & 0.0009 & -0.0099 & 0.0472 & 0.009 & 0.0191 & -0.168 & 0.0865 & 0.9763 & -0.0356 & -0.0555 & $0.8365^{* *}$ \\
\hline
\end{tabular}

Residual effect $=0.015 \quad * *=$ Significant at $1 \%$ level of probability and $*=$ Significant at $5 \%$ level of probability

Note: $\mathrm{PH}=$ Plant height, $\mathrm{PB} / \mathrm{P}=$ Primary branches $/$ plant, TLL $=$ Terminal leaf length, TLB $=$ Terminal leaf breadth, $\mathrm{DFF}=\mathrm{Days}$ to first flowering,

$\mathrm{NN} / \mathrm{P}=$ Number of nodes /plant, $\mathrm{FL}=$ Fruit length, $\mathrm{FG}=$ Fruit girth, $\mathrm{FW} / \mathrm{F}=$ Fresh weight /fruit, $\mathrm{IL}=$ Inter node length and $\mathrm{F} / \mathrm{P}=\mathrm{Fruits} / \mathrm{plant}$. 
The presence of positive as well as negative direct and indirect effects by yield components on yield /plant via one or other characters simultaneously existed a complex situation, where a compromise is required to attain a proper balance of different yield components for determining the model plant for high yield in snake gourd. The characters studied have due consideration at the time of formulation of selection strategy aimed at developing high yielding varieties in snake gourd.

Considerable genetic variability observed in the present investigation for all traits were indicative for the differences in the genetic make-up of the genotypes considered which might offer a great scope for improved breeding programme. Based on yield and yield attributing traits green nitch could be regarded as the most superior and sustainable cultivar. Significant genotypic and phenotypic correlations were found in association between yield and yield contributing traits which could serve as a good index for selection in snake gourd genotypes. Among different quantitative traits fresh weight/fruit had the highest genotypic and phenotypic correlation coefficient and direct effect on yield thus this trait could be a major determiner to sustainable yield.

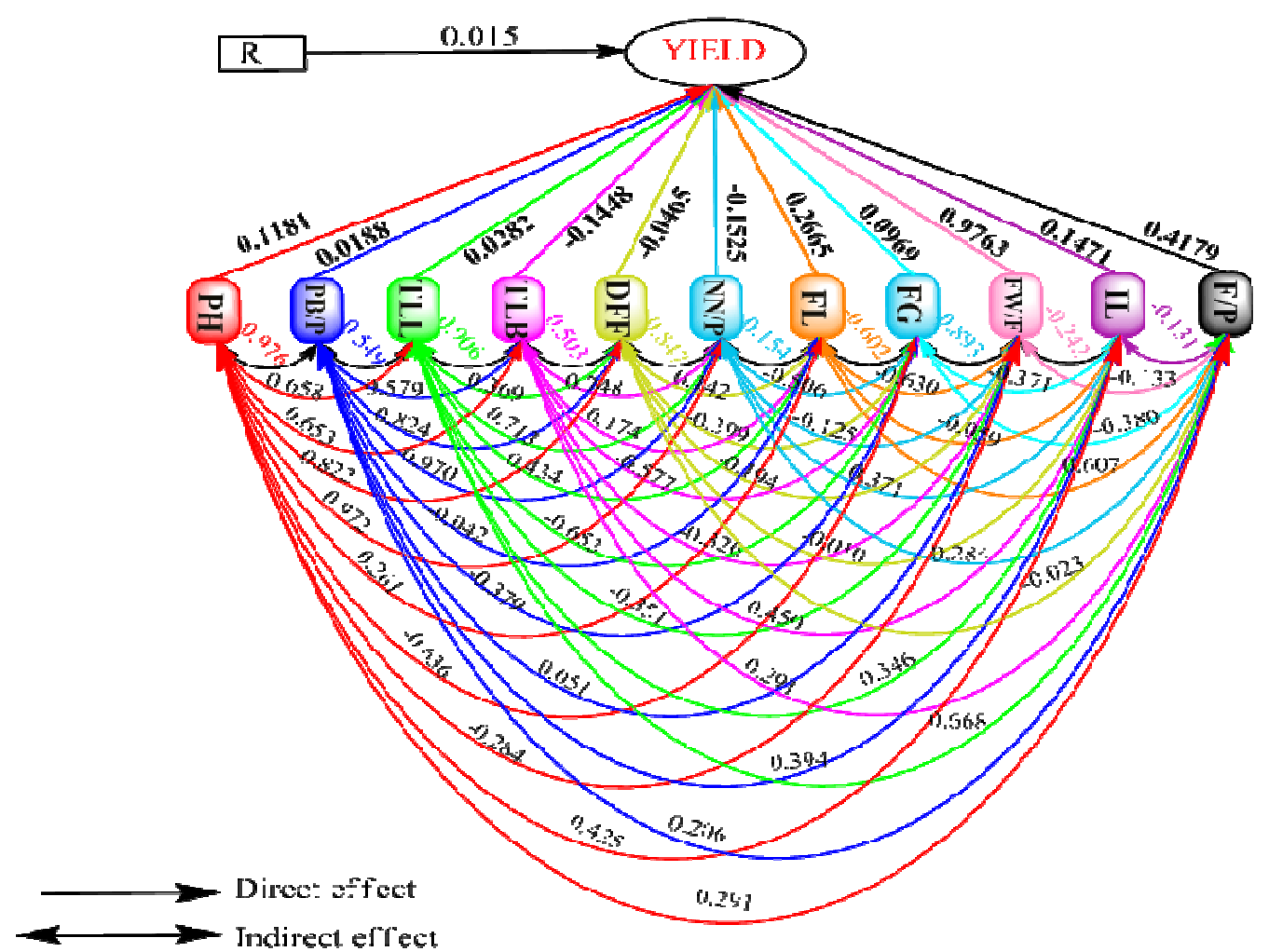

Fig. 1. Path diagram of different yield contributing characters on yield/plant at genotypic level

Note: $\mathrm{PH}=$ Plant height, $\mathrm{PB} / \mathrm{P}=$ Primary branches /plant, TLL= Terminal leaf length, TLB $=$ Terminal leaf breadth, $\mathrm{DFF}=$ Days to first flowering, NN/P= Number of nodes /plant, FL= Fruit length, FG= Fruit girth, $\mathrm{FW} / \mathrm{F}=$ Fresh weight $/$ fruit, $\mathrm{IL}=$ Inter node length and $\mathrm{F} / \mathrm{P}=$ Fruits /plant. 


\section{REFERENCES}

Anonymous. 1998. Year Book of Agricultural Statistics of Bangladesh. Bangladesh Bureau of Statistics, Ministry of Planning, Govt. of the People's Republic of Bangladesh, Dhaka, Bangladesh. pp. 64-88.

BBS. 2007. Yearbook of Agricultural Statistics. 2006. Bangladesh Bureau of Statistics, Ministry of Govt. of the People's Republic of Bangladesh, Dhaka.

Chakarbati, A.K. 1982. Fasicols of flora of India.Cucurbitaceae.Botanical Survey of Hawara.West Bengal, India.

Dewey, D.R. and Lu, K.H. 1959. A correlation and path coefficient analysis of components of crested wheat grass seed production. Agron. J. 51: $575-581$.

Graffius, R. 1964. A geometry for plant breeding. Crop Sci. 4: 241-246.

Haider, J., Marumoto, T. and Azad, A.K. 1991.Estimation of microbial biomass, carbon and nitrogen in Bangladesh soils.Soil Sci. Tech.20: 643-653.

Hanson, C.H., Robinson, H.F. and Comstock, R.E. 1956. Biometrical studies of yield in segregating populations of Korean Lespedza. Agron. J. 48: 268-272.

Huque, A.K.M.M., Hossain, M.K., Alam, N., Hasanuzzaman, M., Biswws, B.K. and Arifuzzaman, M. 2012.Genetic variability, correlation and path analysis for yield and its component characters in string bean (Vigna unguiculatassp. Sesquipedalis L. Verdc.).Jahangirnagar Uni. J. Biol. Sci.1(1): 1-10.

Islam, M.S., Khan, S., Khanam, D., Malek, M.A. and MosiulHoque, A. M. M. 1993a ,b. Genetic variability and path analysis in cucumber (cucumis sativus L.). Bangladesh. J. Pl. Breed. Genet.6: 45-51.

Jeffery, C. 1980. A review of Cucurbita-ceae.Bot. J. Linn. Sco.Land.81: 233-247.

Johnson, H.W., Robinson, H.F., and R.E. Comstock. 1955. Estimation of genetic and environmental variability in soybeans. Agron. J.47: 314-318.

Miah, M.A., Rahman, M.M., Uddin, M.S., Rahman, A.K.M.M. and Ullah, M.H. 2000.Genetic association in bitter gourd (Momordica charantiaL.).Bangladesa. J. Sci. Techol. 2: 21-25.

Narayanankutty, C., Sunanda C.K. and Jaikumaran U. 2006. Genetic variability and character association analysis in snake gourd.ndian Journal of Horticulture. Indian J. Hort. 63(4): 402-406.

Narolia, R. K. Reddy, R. V. S. K. and Padma, M. 2012. Correlation and path coefficient analysis of growth, yield and quality of tomato( Lycopersicon esculantum Milli.). Indian J. Trop. Biodi. 20(1):65-69

Rahman, M.A, Hassain, M.D, Islam, M.S., Biswas, D.K. and M. Ahiduzzaman. 2002a,b. Genetic variability heritability and path analysis in snake gourd (Trichosanthes anguina L.). Pakistan J. of Biol. Sci. 5: 284-86.

Rana, N.P. and Pandit, M.K. 2011.Studies on the genetic variability, character association and path analysis in in snake gourd (Trichosanthes anguina L.) genotypes.J. crop weed 7(2): 9196.

Rao, D.S.R.M., Singh, H., Singh, B., Khola, O.P.S. and Faroda, A.S. 1990. Correlation and path coefficient analysis of seed yield and its components in sesame ( Sesamum indicum L.). Haryana Agric. Univ. J. Res. 20: 273-276.

Rashid, M. M. 1993. Sabjibiggan.1st edition.Bangla Academy, Dhaka, Bangladesh.

Saha, S.R., Mitra, B.N., Hossain, A.E., Jalaluddin, M. and MosiulHoque, A.M.M.M. 1992. Genetic variability and character association and path coefficient analysis in pumpkin (Cucurbita moschata L.).Bangladesh Hort.20: 59-62.

Varghese, P. and Rajan, S. 1993. Genetic variability and heritability studies in snake gourd (Trichosanthes anguinaL.). J. Trop. Agri. 31: 13-17.

Wright, S. 1921. Correlation and causation.J. Agric. Res. 26: 557-585. 